\title{
MODEL EPIDEMI STOKASTIK SIR RANTAI BINOMIAL
}

\author{
(Binomial Chain SIR Stochastic Epidemic Model)
}

\author{
Wulan Rohimasanti ${ }^{1}$, Respatiwulan ${ }^{2}$, Hasih Pratiwi ${ }^{3}$ \\ Universitas Sebelas Maret, Prodi Statistika, Surakarta ${ }^{1}$ \\ Universitas Sebelas Maret, Prodi Statistika, Surakarta² \\ Universitas Sebelas Maret, Prodi Statistika, Surakarta ${ }^{3}$ \\ Jalan Ir.Sutami 36 Kentingan Jebres Surakarta Jawa Tengah, Indonesia \\ Email: wulan.rohima@student.uns.ac.id
}

\begin{abstract}
ABSTRAK
Epidemi adalah kejadian berjangkitnya suatu penyakit menular dalam masyarakat dengan jumlah penderitanya meningkat secara nyata pada waktu dan daerah tertentu. Model Susceptible Infected Recovered (SIR) merupakan suatu model epidemi yang menggambarkan proses penyebaran penyakit dengan karakteristik setiap individu sembuh memiliki kekebalan tubuh permanen. Jumlah individu yang terinfeksi diasumsikan berdistribusi binomial dengan periode penyembuhan bagi individu yang terinfeksi berhingga $(\Re<\infty)$, sehingga individu yang terinfeksi hanya dapat menginfeksi individu lain pada periode ini. Periode penyembuhan $(\Re)$ adalah waktu yang diperlukan individu terinfeksi untuk sembuh dan menjadi kelompok recovered. Kondisi ini dapat pula disebut waktu penularan karena pada kondisi ini individu yang terinfeksi dapat menularkan penyakit pada individu lainnya. Tujuan penelitian ini adalah menurunkan model epidemi stokastik SIR dengan infeksi yang menyebar dalam populasi membentuk rantai penularan yang ditentukan oleh distribusi binomial dan periode penyembuhan bervariasi kemudian dilakukan simulasi model dan memberikan interpretasi. Pada penelitian ini, periode penyembuhan mempengaruhi durasi epidemi. Penelitian dilakukan dengan mengkaji terlebih dahulu asumsi SIR rantai binomial, probabilitas transisi dan melakukan simulasi model. Selanjutnya memberikan $p$ probabilitas penularannya sebesar 0.05 dan 0.1 . Sebagai simulasi, ukuran populasinya diberikan sebesar 80 orang dengan $\mathfrak{R}$ yang diberikan adalah sebesar 2, 4 dan 7. Kesimpulan penelitian didapatkan model epidemi SIR rantai binomial serta model untuk periode penyembuhan yang dibangun sebagai hasil modifikasi merupakan probabilitas transisi yang menggambarkan besar kemungkinan satu individu sucseptible tertentu pada periode $t$ akan berubah menjadi infected untuk pertama kali pada periode $t+1$. Hasil simulasi menunjukkan bahwa semakin besar $\Re$ dan probabilitas penularan maka puncak epidemi semakin tinggi.
\end{abstract}

Kata kunci : Epidemi, model SIR, rantai binomial.

\section{ABSTRACT}

The epidemic is spread of disease that the number of infected increase significantly in certain times and areas. Susceptible Infected Recovered (SIR) model describes the pattern of disease spread which has a characteristic that recovered individuals have permanently immunity. The number of infected individuals are assumed to follow binomial distribution with recovery period $(\Re<\infty)$, so only during this period the infected individual can infect susceptible individuals. Recovery period of individual is period of infected individual becomes recovered. The recovery period can be called the infectious period because infected individual is capable of infecting others. The purpose of this research are to reconstruct SIR stochastic epidemic model with spread of infection in population forms a chain of transsmission determined by binomial distribution and to vary of recovery period, then interpretation through simulation model. Based on simulation observation, recovery period have controlling in duration epidemic. The research was conducted by assuming SIR binomial chain assumptions, transition probability then simulation. Then probability of transmission is given by $p=0.05$ and 0.1. As simulation, the size of population is 80 people with recovery period $\Re$ given by 2, 4 and 7 . The conclusion of the study is model epidemic SIR binomial chain and the model of recovery period were built as a result of the transition probability modification can illustrate the probability of sucseptible individu change to infected individu. The result of simulation is 
when transimission probability is high and $\Re$ increase then the peak of epidemic will be higher.

Keyword: Epidemic, SIR model, binomial chain.

\section{PENDAHULUAN}

Penyakit menular merupakan salah satu permasalahan yang terjadi dalam kehidupan manusia. Penularan penyakit dapat menyebabkan terjadinya epidemi. Wabah penyakit atau epidemi adalah kejadian berjangkitnya suatu penyakit menular dalam masyarakat dengan jumlah penderitanya meningkat secara nyata pada waktu dan daerah tertentu. Model matematika merupakan pendekatan suatu permasalahan nyata dengan formula matematis. Model matematika yang menggambarkan penyebaran penyakit dikenal dengan model epidemi. Salah satu model epidemi yang menggambarkan proses penyebaran penyakit yaitu model susceptible infected recovered (SIR). Menurut Kermack and McKendrick (1927), dalam model ini populasi dibagi ke dalam tiga kelompok, yaitu

1. Susceptible (S), yaitu kelompok individu yang belum mengidap penyakit tetapi berpotensi terserang penyakit setelah terjadi kontak dengan infected

2. Infected (I), yaitu kelompok individu yang terinfeksi dan dapat menularkan penyakit pada individu lain,

3. Recovered $(R)$, yaitu kelompok individu yang terserang penyakit kemudian menjadi sembuh dan tidak dapat terinfeksi kembali.

Model SIR, menurut Brauer, et al. (2008) merupakan suatu model matematika yang menggambarkan pola penyebaran penyakit, dengan setiap individu yang telah sembuh dari infeksi mempunyai sistem kekebalan tubuh. Model epidemi dapat ditinjau secara probabilistik (Term, 2007). Pada model epidemi probabilistik proses penyebaran penyakitnya random dan mempunyai probabilitas tertentu. Perubahan jumlah individu terinfeksi berkaitan dengan probabilitas suatu kejadian. Penyebaran penyakit merupakan suatu kejadian random yang bergantung pada variabel waktu dan berkaitan dengan probabilitas disebut proses stokastik. Menurut Halloran et al (2010), Infeksi menyebar dari individu ke individu pada populasi dalam satuan waktu diskrit, membentuk rantai penularan yang ditentukan oleh distribusi probabilitas binomial. Suatu epidemi dikatakan berhenti apabila tidak ada lagi individu yang terinfeksi.

Penelitian ini bertujuan untuk menurunkan model epidemi stokastik SIR dengan jumlah individu yang terinfeksi berdistribusi binomial dan periode penyembuhan bervariasi kemudian dilakukan simulasi model dan memberikan interpretasi. Penelitian ini diharapkan dapat menambah pengetahuan mengenai model stokastik dengan distribusi binomial dalam hubungannya dengan penyebaran penyakit khususnya SIR.

\section{METODE}

Metode yang digunakan adalah metode studi literatur. Penurunan model ini mengacu pada Tuckwell and Williams (2007). Pada penelitian ini ditentukan asumsi penyebaran penyakit dengan asumsi umum model epidemi SIR serta ditambahkan asumsi adanya periode penyembuhan selama periode tertentu secara berurutan terhitung dari waktu individu pertama kali tertular, ketika individu terinfeksi untuk pertama kali pada periode waktu $t$ maka individu akan tetap dalam keadaan terinfeksi selama periode waktu $\{t, t+1, t+2, \ldots, t+\Re-1\}$ dan setelahnya akan menjadi sembuh. Kejadian perubahan individu susceptible menjadi infected bergantung pada peluang kontak antara sucseptible dengan infected karena individu dalam populasi merupakan kejadian saling asing serta setiap individu yang termasuk dalam kelompok susceptible tidak termasuk dalam kelompok infected maupun recovered. Kemudian menentukan persamaan probabilitas transisi yaitu probabilitas individu kelompok 
susceptible menjadi kelompok infected. Pada model ini jumlah individu infected dipandang sebagai variabel random yang mengikuti distribusi binomial.

\section{HASIL DAN PEMBAHASAN}

Model SIR (Susceptible Infected Recovered) membagi populasi menjadi 3 kelompok yaitu Susceptible (S) adalah kelompok individu yang rentan terhadap penyakit, Infected (I) adalah kelompok individu yang terinfeksi penyakit dan dapat sembuh dan Recovered $(R)$ adalah kelompok individu yang telah sembuh dan kebal terhadap penyakit.

Penurunan model stokastik SIR rantai binomial mengacu pada Tuckwell and Williams (2007). Infeksi menyebar dari individu ke individu pada populasi dalam satuan diskrit, membentuk rantai penularan yang ditentukan oleh distribusi binomial. Probabilitas $p$ menyatakan probabilitas terjadinya perubahan individu kelompok susceptible menjadi kelompok infected atau bisa disebut juga dengan probabilitas penularan. Probabilitas penularan bergantung pada jumlah individu infected, sehingga probabilitias tidak terjadinya penularan jika $I(t)$ individu infected adalah $1-p(I(t))=$ $(1-p)^{I(t)}$. Jumlah infected $I(t+1)$ pada periode waktu $t+1$ yang bergantung pada probabilitas penularan dapat ditentukan berdasarkan harga harapannya, yaitu

$$
I(t+1)=S_{t} p^{I(t)}
$$

Probabilitas terjadinya penularan $(p)$ dipengaruhi oleh banyaknya individu yang terinfeksi sehingga didapatkan probabilitas $p^{I(t)}$ karena sesuai distribusi binomial $I(t)$ adalah $\mathrm{x}$ kali percobaan yang sukses atau individu secseptible berhasil terinfeksi maka $p^{x}=p^{I(t)}$, paling tidak ada satu individu infected yang melakukan kontak dengan individu sucseptible.

\section{Asumsi Model Epidemi SIR Rantai Binomial}

Pada model ini digunakan asumsi model SIR menurut Tuckwell and Williams (2007) yang merupakan asumsi tambahan. Berikut asumsi dari model stokastik SIR:

1. Total populasi konstan $n$

2. Periode waktunya adalah diskrit, $t=0,1,2,3, \ldots$

3. Jumlah individu yang terinfeksi merupakan variabel random berdistribusi binomial. Individu $i$, dengan $i=1, \ldots, n$ dan $I^{i}=\left\{I^{i}(t), t=1,2, \ldots\right\}$ merupakan proses random sedemikian sehingga $I^{i}(t)=1$ jika individu tersebut terinfeksi dan mampu menulari individu lain pada waktu $t . I^{i}(t)=0$ jika individu tidak terinfeksi (succeptible).Jumlah total orang yang terinfeksi pada waktu $t$ adalah

$$
I(t)=\sum_{i=1}^{n} I^{i}(t), \quad t \geq 0
$$

4. Kelompok inidividu $N_{i}(t)$ merupakan sejumlah individu yang melakukan kontak terhadap individu sucseptible, terdiri dari kelompok yang jumlahnya konstan $n_{i}$ individu yang tetap ditemui setiap harinya, seperti kerabat, keluarga ditambah dengan sejumlah random individu $M_{i}(t)$ yang diambil secara random dari individu yang tersisa selama $(t, t+1], N_{i}(t)=n_{i}+$ $M_{i}(t)$.

5. Jika individu terinfeksi pertama kali pada periode $t$ maka individu tersebut dapat menginfeksi individu lainnya pada periode waktu $\{t, t+1, t+2, \ldots, t+$ $\Re-1\}$. Pada periode $t+\Re$ individu tersebut sudah sembuh atau recovered yang artinya tidak dapat tertular kembali. Individu terinfeksi tetap dalam keadaan terinfeksi selama $\mathfrak{R}$ periode berurutan terhitung dari waktu pertama kali individu terinfeksi, dengan $\Re$ adalah sebuah bilangan bulat positif yang tetap.

6. Misalkan $I(t)$ adalah individu infected pada waktu $t$, maka probabilitas individu terpilih secara random untuk terinfeksi adalah probabilitas $\frac{I(t)}{n}$. 


\section{Model dengan Waktu Penyembuhan}

Berdasarkan asumsi nomor individu susceptible yang mengalami kontak dengan individu infected kemudian tertular menjadi infected dapat dinyatakan sebagai $I^{i}(t)=$ 1. Jumlah infected pada periode $t$ akan sembuh pada periode $t+\Re$ yang kemudian masuk kedalam kelompok recovered. Pada periode $t+1$, susceptible yang mengalami kontak dengan infected $I(t)$ dan tertular akan menjadi infected sedangkan yang tidak tertular akan masuk ke kelompok susceptible. Perubahan individu susceptible menjadi individu infected atau tetap susceptible merupakan kejadian yang berdistribusi binomial, sehingga berlaku

$$
S(t)=S(t+1)+I(t+1)
$$

Pada periode $t+1$ terdapat kemungkinan $S(t)$ akan menjadi $S(t+1)$ adalah sebanyak $\left(\begin{array}{c}s(t) \\ s(t+1)\end{array}\right)$. Probabilitas tidak terjadinya penularan antara individu susceptible dengan individu infected adalah $(1-p)^{I(t)}$. Sehingga probabilitas terdapat infected pada periode $t+1$ dituliskan sebagai

$$
P(I(t+1) \mid S(t), I(t))=\left(\begin{array}{c}
S(t) \\
S(t+1)
\end{array}\right)\left(1-(1-p)^{I(t)}\right)^{I(t+1)}(1-p)^{I(t) S(t+1)}
$$

Setiap individu dalam populasi merupakan kejadian saling independen. Menurut Tuckwell and Williams (2007), jumlah individu infected baru pada periode $t+1$ merupakan individu susceptible yang mengalami kontak dengan infected dan tertular pada periode sebelumnya. Sehingga jumlah individu infected baru $\left(I_{0}\right)$ pada periode waktu $t+1$ adalah

$$
I_{0}(t+1)=S(t)-S(t+1)
$$

Apabila individu infected yang terinfeksi pada periode $t$ maka individu tersebut dapat menginfeksi individu lain dan akan tetap berada dalam kondisi infected hingga individu tersebut sembuh dan masuk kedalam individu recovered pada periode waktu $t+\mathfrak{R}$. Jika infeksi berhenti pada periode waktu $m$, maka individu infected pada periode waktu $t$ yang tetap dalam keadaan infected selama $m$ periode, dengan $m=$ $0,1,2, \ldots, \Re-1$ dapat dinyatakan $I_{m}(t)$. Jumlah total individu infected pada periode $t+$ 1 adalah

$$
I(t+1)=\sum_{m=0}^{\Re-1} I_{m}(t+1)
$$

Individu yang terinfeksi (infected) akan mengalami pemulihan dan masuk kedalam individu recovered serta tidak dapat terserang penyakit kembali pada $\mathfrak{R}$ periode berikutnya. Pada periode $\mathfrak{R}-1$ individu infected masih dalam keadaan infected dan dapat menginfeksi individu lain hingga sembuh atau masuk keadaan recovered. Jumlah individu recovered pada periode $t+1$ adalah

$$
R(t+1)=R(t)+I_{\Re-1}(t)
$$

Berdasarkan persamaan diatas didapatkan model epidemi $S I R$ rantai binomial sebagai berikut

$$
\begin{gathered}
S(t+1)=S(t)(1-p)^{I(t)} \\
I(t+1)=\sum_{m=0}^{\Re-1} I_{m}(t+1) \\
R(t+1)=R(t)+I_{\Re-1}(t)
\end{gathered}
$$

\section{Model Waktu Penyembuhan Bernilai Kurang dari Tak Hingga $(\Re<\infty)$}

Pada setiap periode $t$, individu $i$ dimungkinkan dapat berada dalam kelompok susceptible, infected atau recovered. Jika individu $i$ berada dalam kelompok susceptible maka dia tidak berada dalam kelompok infected ataupun recovered. Berdasarkan model yang telah terbentuk didapatkan model pada persamaan (3) dibutuhkan kemungkinan perpindahan individu untuk simulasi proses penyebaran penyakit yaitu probablitas individu $i$ susceptible pada periode $t$ menjadi individu infected untuk pertama kali pada $t+1$ hingga menjadi sembuh dan tidak dapat terjangkit penyakit kembali pada periode waktu $t+\Re$. Probabilitas ini hanya bergantung pada total individu yang terinfeksi pada periode $t(I(t)=y)$ dengan kelompok individu $N_{i}(t)$ yaitu 
sejumlah individu yang ditemui tiap-tiap individu $i$ pada periode $t$ dan $p$ probabilitas penularan tiap kontak. Probabilitas kontak individu $i$ bertemu tepat dengan $j$ infected didalam $N_{i}(t)$ adalah

$$
P_{j}^{i}\left(y, N_{i}(t) ; n\right)=\left(\begin{array}{c}
N_{i}(t) \\
j
\end{array}\right)\left(\frac{y}{n-1}\right)^{j}\left(1-\frac{y}{n-1}\right)^{N_{i}(t)-j}
$$

Probabilitas penularan bergantung pada jumlah individu infected, sehingga probabilitas penularan seseorang menjadi individu infected jika bertemu dengan $j$ infected adalah

$$
P_{j}=1-(1-p)^{j}
$$

Dari persamaan (4) dan (5) dapat dihitung probabilitas individu sucseptible pada periode $t$ menjadi individu infiected untuk pertama kali pada periode $t+1$ dengan

$$
\begin{aligned}
P\left(I_{0}^{i}(t+1)=1 \mid N_{i}(t), S^{i}(t)=\right. & 1, I(t)=y, \ldots)=\sum_{j=1}^{N_{i}(t)} p_{j} P_{j}^{i}\left(y, N_{i}(t) ; n\right) \quad(6) \\
& =\sum_{j=1}^{N_{i}(t)}\left(1-(1-p)^{j} P_{j}^{i}\left(y, N_{i}(t) ; n\right)\right. \\
& =\sum_{j=1}^{N_{i}(t)} P_{j}^{i}\left(y, N_{i}(t) ; n\right)-\sum_{j=1}^{N_{i}(t)}\left(\left((1-p)^{j}\right) P_{j}^{i}\left(y, N_{i}(t) ; n\right)\right) \\
& =1-\sum_{j=1}^{N_{i}(t)}\left((1-p)^{j}\right)\left(\begin{array}{c}
N_{i}(t) \\
j
\end{array}\right)\left(\frac{y}{n-1}\right)^{j}\left(1-\frac{y}{n-1}\right)^{N_{i}(t)-j} \\
& =1-\sum_{j=1}^{N_{i}(t)}\left(\begin{array}{c}
N_{i}(t) \\
j
\end{array}\right)\left(\frac{y}{n-1}-\frac{p y}{n-1}\right)^{j}\left(1-\frac{y}{n-1}\right)^{N_{i}(t)-j}
\end{aligned}
$$

Kemudian persamaan (6) dapat disederhanakan menjadi

$$
P\left(I_{0}^{i}(t+1)=1 \mid N_{i}(t), S^{i}(t)=1, I(t)=y, \ldots\right)=1-\left(1-\frac{p y}{n-1}\right)^{N_{i}(t)}
$$

Jika $i$ adalah individu susceptible pada periode $t$, dengan $N_{i}(t)$ jumlah individu yang bertemu pada periode $t$, dan kemungkinan infeksi pada masing-masing adalah $\frac{p y}{n-1}$, maka probabilitas individu $i$ tidak menjadi individu infected adalah $\left(1-\frac{p y}{n-1}\right)^{N_{i}(t)}$. Pada penelitian Tuckwell and Williams (2007), mengasumsikan bahwa pada waktu $t$ terdapat $I(t)=y$ individu infected, dan tidak ada individu recovered, yang berarti bahwa terdapat $n-y$ individu susceptible dengan $\Re$ periode recovery. Sehingga probabilitas tidak adanya infeksi baru pada $\mathrm{t}+1$ merupakan probabilitas bersama dapat dinyatakan dengan

$$
P\left(I(t+1)=y \mid N_{i}(t), i=1, \ldots, n-y ; I(t)=y\right)=\left(\prod_{i=1}^{n-y}\left(1-\frac{p y}{n-1}\right)^{N_{i}(t)}\right)^{\Re}
$$

Kemudian probabilitas adanya satu infected baru dapat dituliskan dengan peluang marjinal bahwa satu diantara individu sucseptible $i$ menjadi infected pada periode $t+1$ dimana $i=1,2,3, \ldots, n-y$. Probabilitas tersebut dapat dituliskan sebagai berikut

$$
\begin{gathered}
P\left(I(t+1)=y+1 \mid N_{i}(t), i=1, \ldots, n-y ; I(t)=y\right)=\sum_{i=1}^{n-y}(1-(1- \\
\left.\left.\frac{p y}{n-1}\right)^{N_{i}(t)}\right)\left(\prod_{j=1}^{n-y}\left(1-\frac{p y}{n-1}\right)^{N_{i}(t)}\right)^{\Re} \text { (9) }
\end{gathered}
$$

Periode recovery dengan nilai yang berhingga dapat menunjukkan adanya perbedaan yang cukup signifikan pada jumlah individu yang terinfeksi meskipun hanya mengambil nilai periode recovery yang kecil.

\section{Simulasi Model}

Pada simulasi ini diberikan nilai awal jumlah individu yang terinfeksi, $I_{0}(0)=1$ dan ukuran populasi sebesar 80 dengan probabilitas penularan nya 0.05 dan 0.1 serta ditentukan variasi periode recovery $\mathfrak{R}$ dengan nilai 2 , 4 dan 7 . Kemudian simulasi ditentukan dengan menggunakan persamaan 1, 2 dan 3 yang dituliskan secara model umum menjadi persamaan 4, dengan contoh penghitungan sebagai berikut 
Diberikan $p=0.05, t=0 I(0)=1$

$S(1)=S(0)(1-0.05)^{1}=75$

$I(1)=S(0)-S(1)=4$

dan seterusnya hingga nilai sucseptible dan infected mendekati 0.

Lamanya periode recovery $\mathfrak{R}$ dapat mempengaruhi pola penyebaran penyakit. Variasi nilai periode recovery $\mathfrak{R}$ yang diambil adalah 2 , 4, dan 7 dengan $p$ probabilitas penularannya sebesar 0.05 . Perbandingan penyebaran infected dengan periode recovery $\mathfrak{R}$ tersebut akan diperlihatkan pada Gambar 1. Pada gambar tersebut memperlihatkan periode terjadinya infeksi maksimum dengan variasi nilai periode recovery $\mathfrak{R}$ adalah berbeda. Semakin lama periode recovery $\mathfrak{R}$ maka puncak epidemi semakin tinggi dan periode infeksi semakin lama.

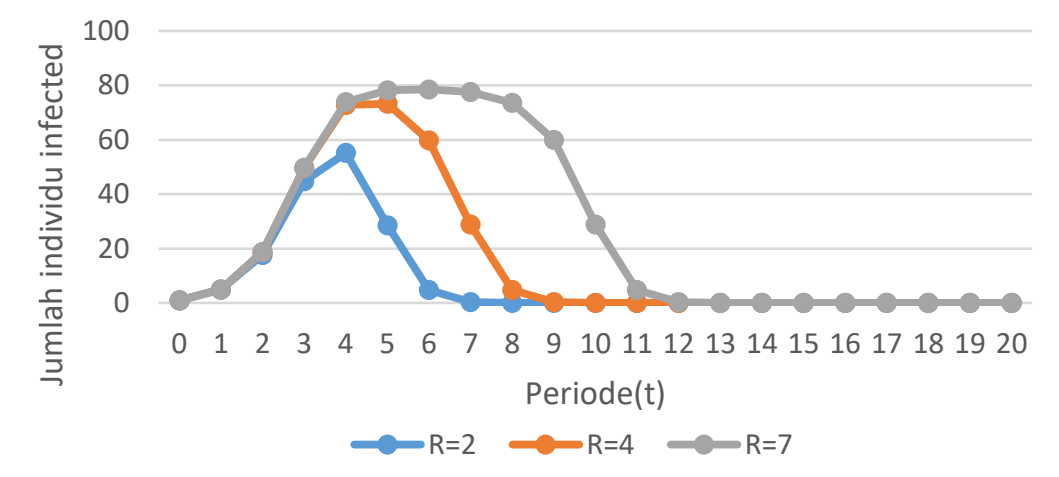

Gambar 1. Pola penyebaran penyakit dengan $\Re=2,4$ dan 7

Selanjutnya pola penyebaran penyakit juga dapat dipengaruhi oleh $p$ probabilitas penularan penyakit. Simulasi berikut masih menggunakan data yang sama namun dibedakan pada nilai probabilitas penyebaran menggunakan $p=0.1$.

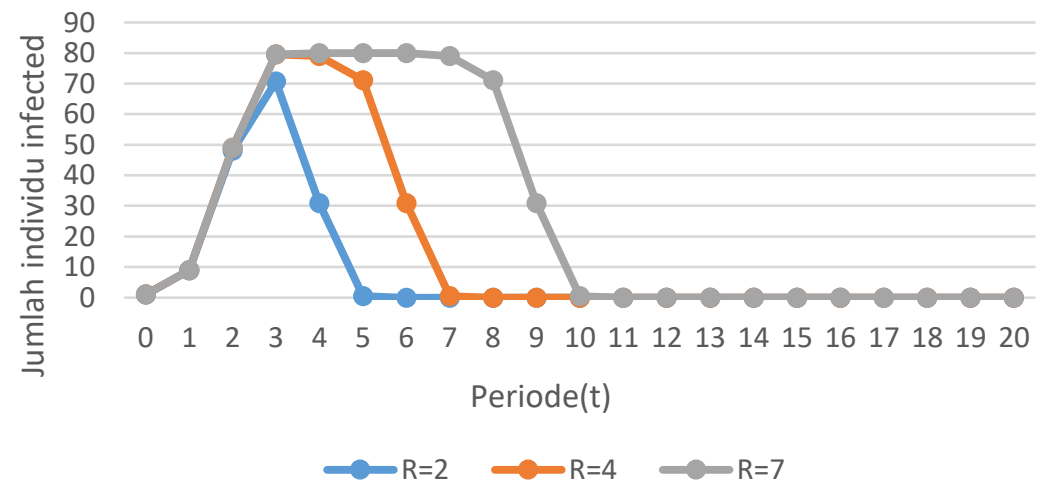

Gambar 2. Pola penyebaran dengan $p=0.1$

Pada Gambar 2 memperlihatkan periode terjadinya infeksi maksimum dengan variasi nilai probabilitas adalah berbeda. Jika dibandingkan dengan Gambar 1 yang memiliki $p=0.05$, maka semakin besar probabilitas 
penularan penyakit, puncak epidemi semakin tinggi dan periode recovery $\Re$ semakin cepat.

\section{KESIMPULAN}

Penelitian ini menyajikan model epidemi susceptible infected recovered (SIR) yang mengasumsikan bahwa infeksi menyebar dalam populasi dengan satuan waktu diskrit dan membentuk rantai penularan yang ditentukan oleh distribusi binomial ditunjukkan pada persamaan (1), (2) dan (3). Model epidemi SIR rantai binomial dengan asumsi adanya periode recovery atau penyembuhan bernilai kurang dari tak hingga $(\Re<\infty)$ bergantung pada total individu yang terinfeksi pada periode $t$ dengan $p$ probabilitas penularan tiap kontak. Pada hasil simulasi yang telah dilakukan diperoleh bahwa puncak epidemi dan lamanya periode bergantung pada jumlah individu infected, lamanya periode recovery (penyembuhan) dan probabilitas penularan.

\section{UCAPAN TERIMAKASIH}

Dalam penyusunan artikel ini tidak terlepas dari dukungan berbagai pihak. Peneliti banyak menerima bimbingan, petunjuk dan bantuan dari berbagai pihak. Peneliti secara khusus mengucapkan terima kasih yang sebesar besarnya kepada semua pihak yang telah berperan dalam proses penelitian Model Epidemi Stokastik SIR Rantai Binomial sehingga penulisan ini dapat dijadikan dalam bentuk tulisan dan diinformasikan kepada pembaca.

\section{DAFTAR PUSTAKA}

Allen, L. J. S. (2008). An Introduction to Stochastic Epidemic Models, Texas Tech University, Texas.

Bain, L. J. and Engelhardt, M. (1992). Introduction to probability and mathematical statistic 2 ed. Duxbury Press: California.

Brauer, F., P. Driessche, and J. Wu. (2008). Mathematical Epidemiology, Springer.

Fine, P. E. M. (1997). A comentary on the Reed-Frost epidemic model. American Journal of Epidemiology No. 106, 87-100

Halloran, M. E., Longini, I. M. and Struchiner, C. J. (2010). Binomial and Stochastic Transmission Models. 63-84. https://doi.org/10.1007/978-0-387-68636-3 4

Hethcote, H.W. (2000). The mathematics of infectious diseases, www.siam.org/journals/sirev/42-4/37190.html Vol 42, 599-653.

Kermack, W.O. and McKendrick, A.G. (1927). A Contributions to the Mathematical Theory of Epidemics. Proceedings of the Royal Society A: Mathematical, Physical and Engineering Sciences, Vol. 115, No. 772, 700-721.

Parzen, E. (1962). Stochastic Processes, Holden-Day, Inc.: United States of America.

Term, H. (2007). Using Probabilistic Models to Infer Infection Rates in Viral Outbreaks.

Tuckwell, H.C. and R.J. Williams. (2007). Some properties of a simple stochastic epidemic model of SIR type. Mathematical Biosciences, Vol 208, No.1, 76-97. 


\section{LAMPIRAN}

Lampiran 1. Hasil penghitungan model hingga $t=8$

\begin{tabular}{cccccccccccccc}
\hline $\begin{array}{c}\text { per } \\
\text { iod } \\
\mathrm{e}\end{array}$ & $\begin{array}{c}\text { Sus } \\
\mathrm{cep} \\
\text { tibl } \\
\mathrm{e}\end{array}$ & 0 & 1 & 2 & 3 & 4 & 5 & 6 & $\begin{array}{c}\text { total } \\
\text { infect } \\
\text { ed } \\
(\mathrm{r}=2)\end{array}$ & $\begin{array}{c}\text { total } \\
\text { infect } \\
\text { ed } \\
(\mathrm{r}=4)\end{array}$ & $\begin{array}{c}\text { total } \\
\text { infecte } \\
\mathrm{d} \\
(\mathrm{r}=7)\end{array}$ & $\begin{array}{c}\text { recov } \\
\text { ered }\end{array}$ & $\begin{array}{c}\text { Total } \\
\text { reco } \\
\text { vere } \\
\mathrm{d}\end{array}$ \\
\hline 0 & 79 & 1 & 0 & 0 & 0 & 0 & 0 & 0 & 1 & 1 & 1 & 0 & 0 \\
1 & 75 & 4 & 1 & 0 & 0 & 0 & 0 & 0 & 5 & 5 & 5 & 0 & 0 \\
2 & 61 & 14 & 4 & 1 & 0 & 0 & 0 & 0 & 18 & 19 & 9 & 0 & 0 \\
3 & 30 & 31 & 14 & 4 & 1 & 0 & 0 & 0 & 45 & 50 & 50 & 0 & 0 \\
4 & 6 & 24 & 31 & 14 & 4 & 1 & 0 & 0 & 55 & 73 & 74 & 0 & 0 \\
5 & 2 & 4 & 24 & 31 & 14 & 4 & 1 & 0 & 28 & 74 & 78 & 0 & 0 \\
6 & 1 & 0 & 4 & 24 & 31 & 14 & 4 & 1 & 5 & 60 & 79 & 0 & 0 \\
7 & 1 & 0 & 0 & 4 & 24 & 31 & 14 & 4 & 1 & 29 & 77 & 1 & 1 \\
8 & 1 & 0 & 0 & 0 & 4 & 24 & 31 & 14 & 0 & 5 & 74 & 4 & 5
\end{tabular}

Lampiran 2. Daftar Notasi

$\begin{array}{ll}S(t) & : \text { jumlah indivdu sucseptible pada periode } t \\ I(t) & : \text { jumlah individu infected pada periode } t \\ I_{m}(t) & : \text { jumlah individu infected pada periode } t \text { dan akan terinfeksi } \\ & \text { selama } m \text { periode } \\ R(t) & : \text { jumlah individu recover pada periode } t \\ \Re & : \text { periode penyembuhan (recovery period) } \\ p & : \text { probabilitas penularan antara individu kelompok infected } \\ & \text { dan individu kelompok sucseptible } \\ N_{i}(t) & : \text { jumlah individu yang bertemu dengan individu i pada } \\ & \text { periode } t\end{array}$

